\title{
Growth and Biomass yield of Oil Palm (Elaeis guineensis) Seedlings as Influenced by Different Rates of Vermicompost
}

\author{
A. N. Ashraf, S. Zulkefly, Salisu M. Adekunle, and Mohd Yusoff A. Samad
}

\begin{abstract}
The effect of palm oil mill effluent vermicompost on growth and vegetative traits of oil palm seedlings was evaluated. Different rates of vermicompost $10 \mathrm{~g}, 20 \mathrm{~g}$ and $30 \mathrm{~g}$ and $20 \mathrm{~g}$ of an NPK blue fertilizer as designated control was used. The experiment was conducted over a period of 120 days. Growth and vegetative traits like plant height, girth size, total dry weight (TDW) and root: shoot ratio (RSR) and foliar nutrient data were collected. Noticeably, the vermicompost and the NPK blue fertilizer were at par in stimulating the growth of the oil as shown in the plant height and girth size. The total dry weight (TDW) and Root: shoot ratio (RSR) showed that the vermicompost especially the higher rates significantly performed equal and positively affected the plant biomass. The nitrogen content was apparent in the plants grown with the highest rate of the vermicompost $30 \mathrm{~g}$ and the fertilizer with a significant effect on the leaf chlorophyll content. The results showed that the vermicompost particularly the higher rates were as suitable as the fertilizer with respect to the growth and vegetative traits.
\end{abstract}

Index Terms -Vermicompost; Oil palm; Elaeis guineensis; NPK fertilizer

\section{INTRODUCTION}

Malaysian palm oil industry has generated an average of 53 million tons of residues each year [1] The indication has shown that a significant increase of oil palm solid wastes and 80 million tons of dry biomass in 2010, which is forecast to rise to 100 million dry tons by the year 2020 [2]. Interestingly, oil palm has an economic life of about 20 to 25 years. Nursery stage takes about 11 to 15 months and the first harvest is done after 32-38 months after planting.

The yield is about $45-56 \%$ of fresh fruit bunch (FFB) and the fleshy mesocarp where oil is obtained. Both the mesocarp and kernel of the fruit produce about 17 ton per hectare per year of oil, and the yield of oil from the kernel is about 40 to $50 \%$. The FFB of 5.8 ton produces about 1 ton of crude palm oil (CPO) [3]. However, growth and yield of oil palm requires high nutrients from nursery stage, hence requires high inherent soil fertility status. When oil palm is planted in soils with low nutrient, requires more agronomic

Published on August 17, 2017.

A. N. Ashraf, is with the Department of Crop Science, Faculty of Agriculture, Universiti Putra Malaysia, 43400 UPM Serdang, Selangor, Malaysia (e-mail: aarif7393@gmail.com).

S. Zulkefly, is with the Institute of plantation studies, Universiti Putra Malaysia, 43400 UPM Serdang, Selangor, Malaysia (e-mail: zulkefly@upm.edu.my).

S.M. Adekunle is with the Department of Crop Science, Faculty of Agriculture, Universiti Putra Malaysia, 43400 UPM Serdang, Selangor, Malaysia (e-mail: salisuadekunle@gmail.com).

M. Y. A. Samad is with the 3Department of Land management, Faculty of Agriculture, Universiti Putra Malaysia, 43400 UPM Serdang, Selangor, Malaysia (e-mail: myusoffas@upm.edu.my). inputs that would ensure adequate yield.

Noticeably, most of the soils used especially in the tropics for oil palm have low organic carbon, low cation exchange capacity and essential nutrients [4]. Interestingly, waste materials from agricultural residue like palm oil mill effluent (POME) as organic fertilizer could replace some of the inorganic fertilizer and as such are environmentally friendly.

Total high solids in POME makes this waste a valuable product and useful as feedstock and organic fertilizer. It is organic in nature and difficult to decompose in its natural conditions. However, when it is applied to the soil, it is easily digested by earthworms producing valuable products serving as vermicompost.

Speedy biotechnological procedure to convert the organic substance into stabilized humus-like byproducts using worms has made vermicompost a cost effective among organic materials for plant growth [5].

The use of vermicompost has gained more attention in oil palm plantation due to its effective and usefulness as a rich source of nutrients as organic fertilizer [6]. Many research works have shown that organic waste potentially provides nutrients and enhance soil quality.

The use of compost and vermicompost to improve plant growth and quality had been previously reported. Studies have found that vermicompost promotes root formation [7] increase fruit setting and yield [8] as well as plant dry biomass [9].

Studies have shown potential use of plantation wastes for increasing income with the help of technology and to prevent environmental pollution. The waste materials could be processed into oyster mushrooms, livestock feed and vermicompost and other essential products for sustainable income.

However, vermicompost contains inherent essential nutrient than many organic wastes and has proven to meet nitrogen and phosphorus requirement of plantations crops [10]. Therefore, the study was conducted to evaluate effects of different rates of vermicompost on oil palm seedlings and to reduce the rate of chemical fertilizer used in oil palm nursery.

\section{MATERIALS AND METHODS}

\section{A. Experimental design and treatments}

The study was conducted under rain shelter at field 10, Universiti Putra Malaysia. Three months old oil palm seedlings of GH 500 series variety germinated in $15 \times 23 \mathrm{~cm}$ poly-bag were obtained from Golden Hope Plantation Berhad (GHPB), which is a cultivar of selected elite Deli 
dura with the second generation of BM 119 Pisiferas. Planting medium such as topsoil, peat moss, and sand was prepared in ratio $3: 1: 1$. The three medium were thoroughly mixed and filled in $38 \times 51 \mathrm{~cm}$ polybag to three-quarter of polybag.

Thereafter, the seedlings were transplanted in the polybag and arranged in a completely randomized design (CRD) with four treatments and three replicates. Each replication contained two plants.

The treatments were different rates of vermicompost and compound fertilizer of NPK Blue with formulation ratio $\left(12 \mathrm{~N}: 12 \quad \mathrm{P}_{2} \mathrm{O} 5: 17 \quad \mathrm{~K} 2 \mathrm{O}: 2 \quad \mathrm{MgO}\right)$ designated control treatment. The treatments were coded as T1 control NPK Blue $(20 \mathrm{~g}), \quad$ T2 $(10 \mathrm{~g})$ Vermicompost, T3 (20 g) Vermicompost and T4 (30 g) Vermicompost. The treatments were applied at four weeks' interval for duration of four months.

\section{B. Measurement of the plant growth and vegetative traits}

The height of the plant was taken every two weeks during the growing period. The height was taken from top of planting medium to the tip of the highest leaf using a standard measuring tape. Plant girth size of plants was measured using a digital Vernier caliper. Chlorophyll value was taken with a SPAD-502 meter. Triplicate readings were taken around the midrib of each leaf and averaged.

The seedlings were harvested after 4 months. Root and shoot were carefully removed from planting medium to prevent roots from being broken. The plants were cut into the shoot and root parts thoroughly washed with distilled water. Thereafter, the plants were measured for fresh weight, before oven dried at $65^{\circ} \mathrm{C}$ for $48-72$ hours for determination of the plant total dry weight. Root/shoot ratio was also determined using (1);

$$
R S R=\left(\frac{\text { Total root dry weight }(g)}{\text { Total shoot dry weight }(g)}\right)
$$

\section{Foliar nutrient analysis}

The nitrogen content in plant tissue was determined using the Kjeldahl procedure [11]. Dry ashing method was used to determine macronutrients and micronutrients content in plant tissue, such as phosphorus $(\mathrm{P})$, potassium $(\mathrm{K})$, calcium (Ca) and magnesium (Mg). A $0.35 \mathrm{~g}$ of oven dried ground tissue subsamples were placed into muffle furnace.

The samples were heated at $300^{\circ} \mathrm{C}$ for first 1 hour, then, the temperature was increased at $500^{\circ} \mathrm{C}$ for other 5 hours. The samples were heated to become ash and pale in color. Thereafter, the samples were left to cool overnight. A drop of distilled water and $2 \mathrm{ml}$ of concentrated hydrochloric acid were added.

The samples were placed on a hot plate at $150^{\circ} \mathrm{C}$ until it became dry. Finally, the samples were added with $10 \mathrm{ml}$ of nitric acid ( $20 \%$ by volume) and placed into water bath at $80 \mathrm{oC}$ for 1 hour. The solution were filtered and diluted to $100 \mathrm{ml}$ in volumetric flask. Thereafter, the solution was analyzed using atomic absorption spectrophotometer (AAS) for the nutrients. For $\mathrm{Ca}$ and $\mathrm{Mg}$, the samples were diluted 10 times with strontium chlorite $(1 \mathrm{M})$ before the analysis. All the data were subjected to analysis of variance (ANOVA) using statistical analysis system (SAS Ver 9.4).
Means and standard errors were calculated and Least Significant Difference (LSD) was used for mean separation.

\section{RESULTS}

\section{A. Plant growth and vegetative traits}

There was no significant difference between the height of plants grown with different rates of vermicompost and NPK fertilizer during the first and the second month of plant growth Fig. 1.

In the third month plants grown with the rates, $20 \mathrm{~g}$ and $30 \mathrm{~g}$ of vermicompost and the $20 \mathrm{~g}$ of NPK fertilizer were significantly different from the plants grown with $10 \mathrm{~g}$ of vermicompost. On the other hand, during the fourth month of the plant growth, the height of the plants grown with different rates of vermicompost and NPK was not significantly different.

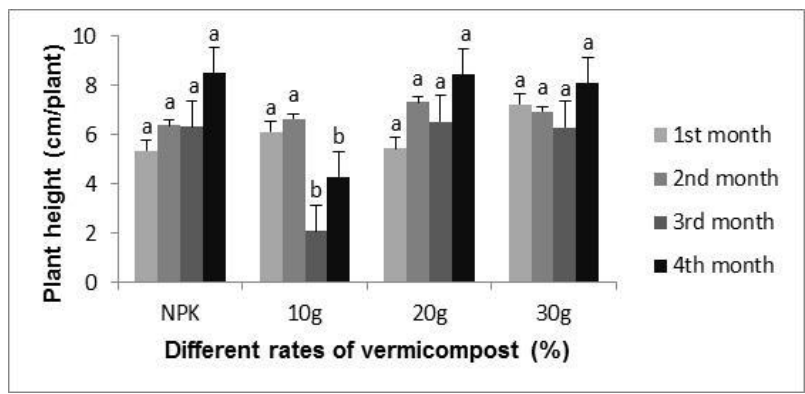

Fig. 1. Effects of different rates of vermicompost on plant height of oil palm seedlings in each month. Means sharing the similar letter in the figure for different rates of the vermicompost and NPK Blue in each month are statistically non-significant $\mathrm{p}<0.05$.

The plants showed superior responses when the treatment NPK, $20 \mathrm{~g}$, and $30 \mathrm{~g}$ of vermicompost were applied compared to $10 \mathrm{~g}$ of vermicompost which had the lowest mean value $4.27 \mathrm{~cm}$. The results indicated significant differences among the treatments relating to the plant girth size in the first month of treatments $p<0.01$ (Fig. 2).

In the first month of planting, there was a significant difference between plants grown with $10 \mathrm{~g}$ of the vermicompost and NPK fertilizer as the plants responded greatly when former was applied.

Similarly, there was a significant difference between plants grown with $10 \mathrm{~g}$ and $20 \mathrm{~g}$ of the vermicompost as the former greatly increased the plant girth size. On the other hand, there was no significant difference between plants grown with $10 \mathrm{~g}$ and $30 \mathrm{~g}$ of the vermicompost during the same month.

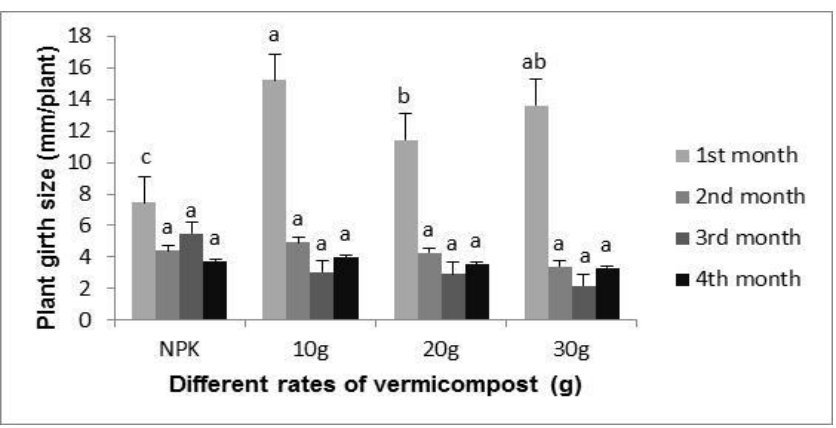

Fig. 2. Effects of different rates of vermicompost on plant height of oil palm seedlings in each month. Means sharing the similar letter in the figure for different rates of the vermicompost and NPK Blue in each month are statistically non-significant $\mathrm{p}<0.05$. 
There were no significant differences between the plants grown with the respective treatments during the subsequent months. However, the results showed the effectiveness of the different rates of vermicompost as the NPK (control) on the plant girth increment. There was no significant difference between the chlorophyll content of the plants grown with different rates of vermicompost and NPK fertilizer during the first and the second month of plant growth Fig. 3.

In the first month after planting, there was no significant difference between chlorophyll content of the plants grown with different rates of the vermicompost and NPK fertilizer. However, the plants grown with $30 \mathrm{~g}$ had a high value of chlorophyll content.

During the second month of application, there was a significant different between the plants as plants grown with NPK had a higher chlorophyll content compared to plants grown with different rates of the vermicompost.

Noticeably, there was no significant difference between chlorophyll content of the plants grown with $10 \mathrm{~g}, 20 \mathrm{~g}$ and $30 \mathrm{~g}$ of different rates of vermicompost. There was a significant difference between the plants as the chlorophyll content of the plants grown with $10 \mathrm{~g}$ and $20 \mathrm{~g}$ and NPK were significantly greater than plants grown with the highest rate $30 \mathrm{~g}$ of the vermicompost. However, there was no significant difference between plants grown with $10 \mathrm{~g}$ and $20 \mathrm{~g}$ and NPK fertilizer.

In the last planting, there was a significant difference between plants grown with $20 \mathrm{~g}$ and $30 \mathrm{~g}$ and $10 \mathrm{~g}$ of the vermicompost. But there was no significant difference between plants grown with NPK and $10 \mathrm{~g}$ of the vermicompost.

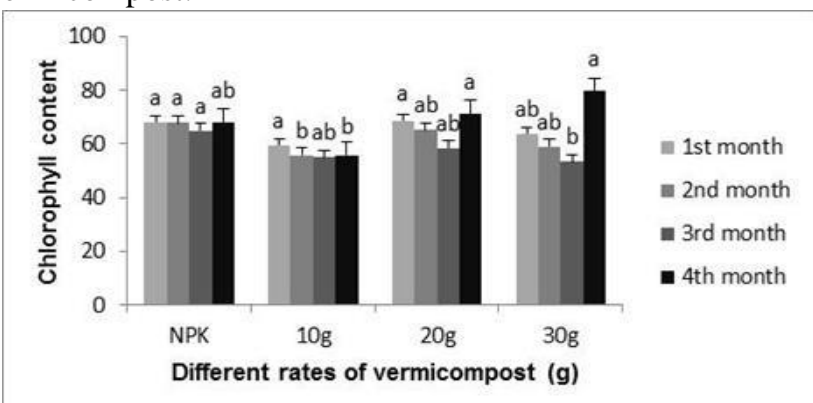

Fig. 3. Effects of different rates of vermicompost on chlorophyll content of oil palm seedlings in each month. Means sharing the similar letter in the figure for different rates of the vermicompost and NPK Blue in each month are statistically non-significant $\mathrm{p}<0.05$.

The results indicated a total dry weight (TDW) over a period of four months Fig. 4. There were no significant differences among the plants grown with the different rates of vermicompost and the NPK fertilizer.

However, the value recorded from the plants that were grown with $20 \mathrm{~g}$ of vermicompost was significant and was the highest. Similarly, there were no significant differences between the plants in terms of the plant root: shoot ratio Fig. 5. This had shown that the vermicompost could competitively perform as the NPK Blue fertilizer.

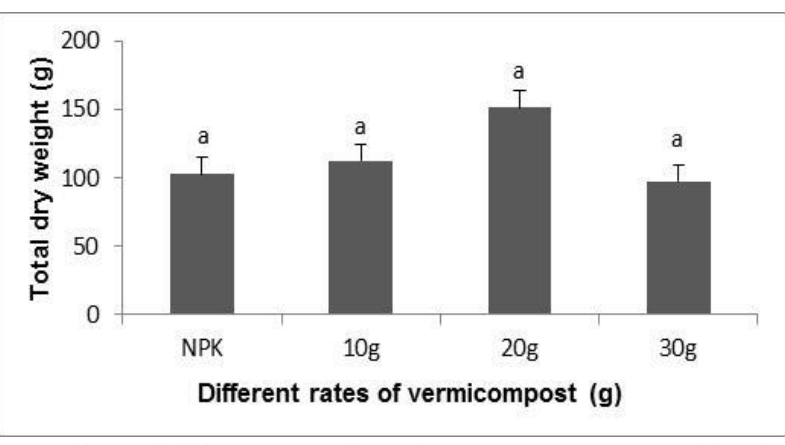

Fig. 4. Effects of different rates of vermicompost on total dry weight of oil palm seedlings in each month. Means sharing the similar letter in the figure for different rates of the vermicompost and NPK Blue are statistically nonsignificant $\mathrm{p}<0.05$.

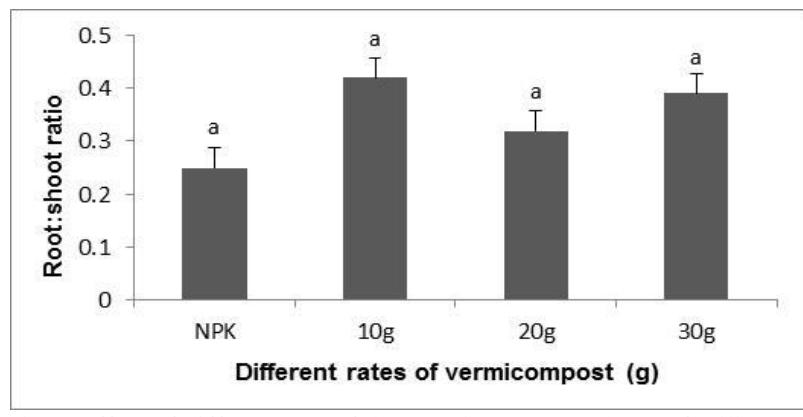

Fig 5. Effect of different rate of the vermicompost and NKP fertilizer on root: shoot ratio of oil palm seedlings. Means sharing the similar letter in the figure for different rates of the vermicompost and NPK Blue are statistically non-significant $\mathrm{p}<0.05$.

\section{B. Foliar nutrient concentration}

The foliar nutrient indicated a significant difference between the plants grown with different rates of vermicompost and the NPK fertilizer Fig. 6a. The plants grown with $10 \mathrm{~g}$ of vermicompost had the lowest $\mathrm{N}$ foliar concentration but were not significantly different from the plants grown with the $20 \mathrm{~g}$ of the vermicompost. This confirms the lower chlorophyll content recorded in the treatment at the two months after planting.

Furthermore, there was a significant difference of calcium (Ca) concentration. Noticeably, the plants grown with $10 \mathrm{~g}$ and $30 \mathrm{~g}$ of the vermicompost had the highest concentration and significantly different from plants grown with the NPK fertilizer. However, there was no significant difference between plants grown with the NPK fertilizer and $20 \mathrm{~g}$ of the vermicompost.
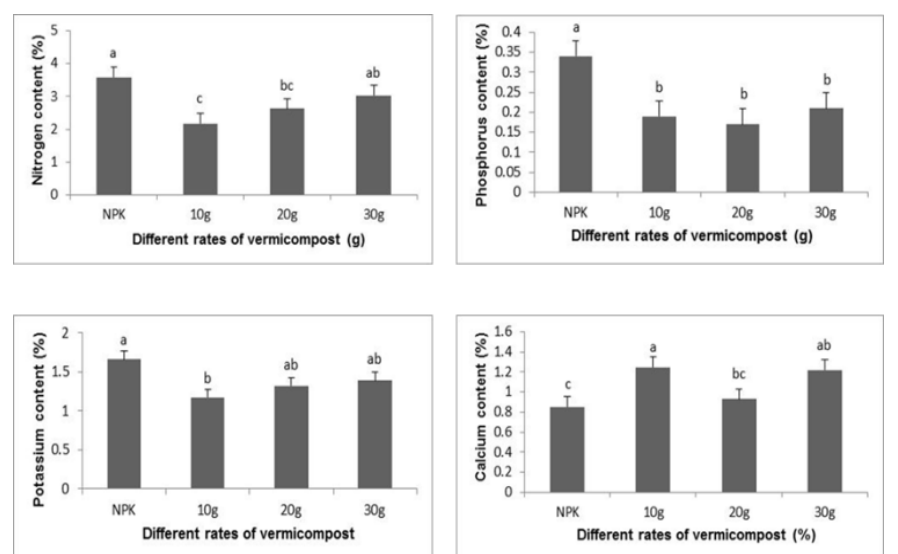

Fig. 6. Effect of NPK fertilizer and different rate of vermicompost on foliar nutrient concentration of oil palm seedlings. Means sharing similar letter in a figure for different rates of the vermicompost and NPK Blue are statistically non-significant $\mathrm{p}<0.05$. 
The plants grown with the NPK fertilizer had the highest mean value of leaf phosphorus concentration with $0.34 \%$ compared to the $10 \mathrm{~g}, 20 \mathrm{~g}$, and $30 \mathrm{~g}$ of the vermicompost. Similarly, there was a significant difference in potassium concentration in a leaf of the oil palm as plants are grown with NPK, recorded a higher concentration compared to the plants grown with $10 \mathrm{~g}$ of the vermicompost.

However, there was no significant difference between the plants grown with the NPK fertilizer and plants grown with $20 \mathrm{~g}$ and $30 \mathrm{~g}$ of the vermicompost. This indicated that higher rates of vermicompost similar to the NPK fertilizer could supply require nutrients like $\mathrm{K}$ for plant optimum growth. Meanwhile, the former could reduce environmental pollution due to its organic nature.

\section{DISCUSSION}

The study showed that the application of the high rate of vermicompost indicated a continuous increment of the plant height and the girth size of the oil palm seedlings until the fourth month of planting. This indicated that high rates of vermicompost could optimally support plant growth like the control treatment (NPK) fertilizer. This is in agreement with the study conducted by [12] who observed that vermicompost efficiently support plant growth as NPK does because it contained high nutrient and microbial activity against some pests.

Plants that were grown with vermicompost had the same results of plant growth with NPK fertilizer [13]. The plant growth increment could have been contributed by the presence of nitrogen-fixing bacteria (NFB) in the final product of the vermicompost as previously reported by [14]

A similar scenario was observed with regards to the chlorophyll content in the oil palm seedlings but higher values were recorded at fourth months of planting particularly when $20 \mathrm{~g}$ and $30 \mathrm{~g}$ of the vermicompost were applied. This could have been contributed by the nitrogen content of the vermicompost. This is supported by [15] who noted that leaf chlorophyll content is often correlated with leaf nitrogen status and photosynthetic activity. Interestingly, the plants treated with the vermicompost also had the higher $\mathrm{N}$ content.

Furthermore, [16] had equally reported a strong correlation between nitrogen and leaf chlorophyll content from the study conducted on maize. There was no significant difference among the treatments on the total dry weight of oil palm seedlings. However, the vermicompost recorded the higher values and performed at par with the NPK fertilizer.

Effect of different rates of vermicompost on the nutrient concentration in oil palm seedling leaves indicated its utilization varies among the seedlings. Apparently, there was a high concentration of nitrogen with respect to the plants that received NPK, $20 \mathrm{~g}$ and $30 \mathrm{~g}$ of the vermicompost. The nutrient concentration within required range; $\mathrm{N} 2.6 \%, \mathrm{P} 3.0 \%, 0.16-\mathrm{K} 0.25 \%$ and $\mathrm{Ca} 1.10 \%$ for optimum growth of oil palm seedlings [17].

The $\mathrm{N}$ concentration could have contributed to the biomass growth particularly the leaf biomass of the plants as previously reported in total dry weight and root: shoot ratio. This is similar to the result of another study conducted by which stated that application of fertilizer containing higher
$\mathrm{N}$ could guarantee higher biomass such as shoot and total dry weight of oil palm seedlings [18] Nitrogen application increases leaf area and improves leaf production and the net assimilation rate of oil palms [19].

More so, nitrogen is more available in leaves of many plants that other parts [20]. Plant vegetative increases when $\mathrm{N}$ is applied to oil palm seedlings. An increase in canopy size leads directly to improved net assimilation and increased biomass production .Meanwhile, leaf $\mathrm{N}$ concentrations $<2.6 \%$ in young palms $\leq 5$ years after planting) could indicate $\mathrm{N}$ deficiency and suggest the requirement for a corrective application of $\mathrm{N}$ fertilizer.

Noticeably, only plants that were grown with NPK Blue significantly had high phosphorus concentration. However, the value recorded in other plants that were grown with vermicompost could be considered suitable for oil palm seedlings.

Phosphorus deficiency in soils could be corrected using organic phosphorus mineralization; thus, organic phosphorus is significant for plant nutrition [21]. Both the vermicompost and the NPK fertilizer showed apparently indicated the same level of potassium concentration in the oil palm leaf. This showed that the treatments particularly the vermicompost could serve as soil amelioration in Malaysian soils and other tropical countries.

The soils in Malaysia are generally poor in $\mathrm{K}$ and the $\mathrm{K}$ is a prime requirement for the maintenance of soil fertility and thus to ensure sustainable growth and yield of oil palms. Though, the deficiency of $\mathrm{K}$ is mostly found in sandy and peat soils in some oil palm plantation [22].

Higher calcium concentration was recorded in the plants grown at various rates of the vermin compost compared to the NPK Blue fertilizer. Studies had shown no significant change in the growth of rubber seedlings planted on soil when compared to the seedlings that were grown on soilless potting mix due to the soil poor properties [23].

\section{CONCLUSION}

The study indicated that both the vermicompost and the NPK fertilizer greatly increased the growth of oil palm seedlings. Noticeably, the higher rates of the vermicompost and the NPK fertilizer were at par on the plant height and girth size increment. This indicated that the vermicompost could significantly support plants growth as the chemical fertilizer.

Also, the total dry weight (TDW) and root: shoot ratio over a period of the four months showed that the vermicompost especially the higher rates could perform equally and support plant biomass production. Nutrients concentration particularly the foliar $\mathrm{N}$ in the plants grown with the highest rate of the vermicompost and the NPK fertilizer was higher nitrogen which translated to higher chlorophyll content and increased plants growth.

The nutrient content particularly the potassium of the plants grown with higher rates of the vermicompost and the NPK fertilizer had the same foliar concentration while calcium was apparent in the plants grown with different rates of the vermicompost compared to the plants grown with the chemical fertilizer.

Considering the organic nature of the vermicompost and its equal performance in terms of the plant growth and 
biomass development, it is recommended for growing the oil palm seedlings and the environmental degradation would be drastically reduced.

\section{ACKNOWLEDGMENT}

The authors would like to thank University Putra Malaysia for the grant in supporting of the research. We equally thank the staff of the research field 2 of the university where the research was conducted and analytical laboratory of the department of crop science for their support throughout the experiment.

\section{REFERENCES}

[1] MPOB, APOC: Palm Oil Development and Performance in Malaysia. Presentation to USITC Washington DC. 2010.

[2] Agensi Inovasi Malaysia, "National Biomass Strategy 2020: New wealth creation for Malaysia's palm oil industry." Available: http://feldaglobal.com/sitecontent/National\%20Biomass\%20Strategy \%20Nov\%2020 11\%20FINAL.pdf. 2012.

[3] R. P. M. Singh, H. I. Norizan Esa, and M. S. Iliyana. (September 2010) Composting of waste from palm oil mill: a sustainable waste management practice. Reviews in Environmental Science and Biotechnology [Online].9 (4). pp. 331-344. Available: https://link.springer.com/article/10.1007/s11157-010-9199-2.

[4] M.A .Salisu and W.D Noordin. (September 2016). Effect of Fertilizer rates and Soil Series on Root Morphological Traits and Root: Shoo Ratio of Immature Natural Rubber (Hevea brasiliensis). International Journal of Scientific and Engineering Research [Online] 7(9) pp. 1373 - 1378. Available: https://www.ijser.org/researchpaper/

[5] S Suthar. (November 2010). Recycling of agro-industrial sludge through vermitechnology. Ecological Engineering [Online]. 8 (36) pp. 1028-1036. Available: http://www.sciencedirect.com/science/article/pii/S0925857410000881

[6] P. F., Rupani, R. P., Singh, M. H., Ibrahim, and Esa, N. (November 2010). Review of current palm oil mill effluent (POME) treatment methods: vermicomposting as a sustainable practice. World Applied Sciences Journal. [Online] 11(1). pp. 70-81. Available: https://www.researchgate.net/profile/Rajeev_Singh19/publication.

[7] N. Q. Arancon, C. A., Edwards, and P. Bierman, (April 2006). "Influences of vermicomposts on field strawberries: Part 2. Effects on soil microbiological and chemical properties". Bioresource Technology. [Online] 97(6). pp. 831-840. Available: http://www.sciencedirect.com/science/article/pii/S096085240500221

[8] N. Q. Arancon, C. A. Edwards, P. Bierman, C. Welch and J. D. Metzger (June 2004). Influences of vermicomposts on field strawberries: 1. Effects on growth and yields. Bioresource technology. [Online]. 93(2). pp. 145-153. Available: http://www.sciencedirect.com/science/article/pii/S0960852403003043

[9] S. Subler, C. Edwards, and J. Metzger, (July 1998). Comparing vermicomposts and composts. Biocycle. [Online] 39 (7). pp. 63-66. Available: http://cat.inist.fr/?aModele=afficheN\&cpsidt=2355334

[10] S. Sadasivuni, R. Bhat, and C. Pallem. (July 2015). Recycling potential of organic wastes of arecanut and cocoa in India: a short review . Environmental Technology Reviews. [Online]. 4(1). pp. 91102.Available:http://www.tandfonline.com/doi/abs/10.1080/0959333 0.2015 .1077897
[11] J. M. Bremner, Nitrogen-total, 1st ed. Sparks D.L, Bartels J.M and Bigham J.M Madison: Wiscosin., 1996, ch. 3, p. 1085-1121.

[12] A. G. Little, and Y. J. Cardoza, (October 2011). Host plant effects on generalist and specialist lepidopterous cabbage pests modulated by organic soil amendment. Pedobiologia. [Online]. 54(5). pp. 353-359. Available:http://www.sciencedirect.com/science/article/pii/S0031405 611000746

[13] S. Paul. and S. S. Bhattacharya. (June 2012). Vermicomposted water hyacinth enhances growth and yield of marigold by improving nutrient availability in soils of north bank plain of Assam. Research and Reviews: Journal of Agricultural Science and Technology. [Online] 2(1). pp. 36-46.Available: https://www.researchgate.net/profile/Satya_Sundar.

[14] S. S. Bhattacharya and G. N.Chattopadhyay, (December 2004), Transformation of nitrogen during vermicomposting of fly ash. Waste management and research. [Online]. 22(6). pp. 488-491. Available: http://journals.sagepub.com/doi/abs/10.1177/0734242X04048625

[15] J. R. Seemann, T. D. Sharkey, J. Wang, and C. B. Osmond, (July 1987). Environmental effects on photosynthesis, nitrogen-use efficiency, and metabolite pools in leaves of sun and shade plants. Plant physiology. [Online] 84(3). pp. 796-802. Available: http://www.plantphysiol.org/content/84/3/796.short.

[16] M. Schlemmer, A. Gitelson, J. Schepers, R. Ferguson, Y. Peng, J. Shanahan, and D. Rundquist, (December 2013). Remote estimation of nitrogen and chlorophyll contents in maize at leaf and canopy levels. International Journal of Applied Earth Observation and Geoinformation. [Online] (25) pp.47-54. Available: http://www.sciencedirect.com/science/article/pii/S0303243413000469

[17] H.R. von Uexküll. and T.H. Fairhurst, "Fertilizing for high yield and quality": The oilpalm. International Potash Institute Bulletin, Vol. 12, p. 79. 1991.

[18] H. Mohidin, M. M. Hanafi, Y. M. Rafii, S. N. A. Abdullah, A. S.Idris, S. Man and M. Sahebi. (July 2015). Determination of optimum levels of nitrogen, phosphorus and potassium of oil palm seedlings in solution culture. Bragantia [Online]. 74(3). pp. 247-254. Available: http://www.scielo.br/scielo.php?pid=S0006-8705201500500040.

[19] R. H. V. Corley and C. K. Mok. (October 1972). Effects of nitrogen, phosphorus, potassium and magnesium on growth of the oil palm. Experimental Agriculture. [Online] 8(4). pp. 347-353. Available: https://www.cambridge.org/core/journals/experimental-agriculture.

[20] M. N. Naugraiya, and A. S. Sisodia. (2015). Potentialities of dalbergia sissoo to reclaim soil fertility of red lateritic wasteland of chhattisgarh. Advances in Tree Seed Science and Silviculture. [Online]. pp. 240. Available: https://www.researchgate.net/profile/P

[21] B.L, Turner "Organic phosphorus transfer from terrestrial to aquatic environments". eds. Turner B.L., Frossard E.and Baldwin D.S. Organic phosphorus in the environment, $\mathrm{CAB}$ International, Wallingford. 2005 pp. 269- 294.

[22] F. Marzukhi, A. L. Elahami, and S. N. Bohari, "Detecting nutrients deficiencies of oil palm trees using remotely sensed data". IOP Conference Series, ed. Earth and Environmental Sci p. 012040. Vol. 37, IOP Publishing, 2016.

[23] M. A. Salisu, W. D. Noordin, Z. Sulaiman, and R. A. Halim, (March 2017). Influence of soilless potting media on growth and vegetative traits of immature rubber (Hevea brasiliensis mull. Arg.). Bangladesh Journal of Botany. [Online] 46(1). pp. 451-457. Available: http://www.bdbotsociety.org/journal/journal_issue/2017\%20March\% 20Supplementary/27. 